\title{
Induction of specific enzymes of the oxidative pentose phosphate pathway by glucono- $\delta$-lactone in Saccharomyces cerevisiae
}

\author{
Anindya Sinha* and Pabitra K. MaItra \\ Molecular Biology Unit, Tata Institute of Fundamental Research, Dr Homi Bhabha Road, Bombay 400 005, India
}

(Received 24 October 1991; revised 17 February 1992; accepted 7 May 1992)

\begin{abstract}
Growth of Saccharomyces cerevisiae on D-glucono- $\delta$-lactone $(\delta \mathrm{gl})$ was found to be associated with a specific coordinate induction of the synthesis of two enzymes of the oxidative pentose phosphate pathway - 6-phosphogluconate dehydrogenase and 6-phosphogluconolactonase - together with that of a third enzyme, gluconokinase. The gnd 1 mutation, responsible for an approximately $80 \%$ loss of 6-phosphogluconate dehydrogenase activity and the inability of the cells to grow on $\delta \mathrm{gl}$, completely abolished the induction of all three enzymes, while the gnd 2 mutation affected this only partially. One class of gndl revertants, selected for growth on $\delta$ gl, was found to have recovered normal dehydrogenase activity and the ability to synthesize the three enzymes when induced by $\delta$ gl. Another class of $\delta$ gl-positive revertants possessed constitutively elevated levels of gluconokinase. In contrast, glucose-positive revertants of gndl, with restored constitutive dehydrogenase activity, continued to remain deficient in induction of the three enzymes and also failed to grow on $\delta$ gl. Induction of 6-phosphogluconate dehydrogenase activity was associated with increased transcription of the gene coding for the major isoenzyme; the transcript remained undetectable in the gndl mutant. Induction of these specific enzymes thus appears to be essential for growth of $S$. cerevisiae on $\delta$ gl.
\end{abstract}

\section{Introduction}

The pentose phosphate pathway has been traditionally considered a biosynthetic route to ribose 5-phosphate for nucleotide and nucleic acid synthesis, erythrose 4phosphate, the precursor of the aromatic skeleton, and NADPH for reductive steps in cellular biosynthesis. It remains, however, perhaps the least studied of all the important metabolic pathways in Saccharomyces cerevisiae. This could possibly be attributed to this yeast being rather conservative in its ability to use pentoses, carbon sources which can be metabolized directly through this pathway, for growth (see Fraenkel, 1982, 1986). The functions and regulation of both the oxidative and non-oxidative branches of this pathway thus remain largely unknown.

Glucono- $\delta$-lactone $(\delta \mathrm{gl})$, the $1-4$ lactone of D-gluconic acid, can serve as a poor carbon source for $S$. cerevisiae

Abbreviations: $\delta \mathrm{gl}$, glucono- $\delta$-lactone; GND, 6-phosphogluconate dehydrogenase; PGL, 6-phosphogluconolactonase; GNK, gluconokinase; GPD, glucose-6-phosphate dehydrogenase.

* Author for correspondence. Present address: Centre for Ecological Sciences, Indian Institute of Science, Bangalore 560 012, India. Tel. 812 340985; fax 812 341683; e-mail cesrg@ces.iisc.ernet.in.
(Gancedo \& Delgado, 1984). Since it is a hexose which could be catabolized exclusively through the pentose phosphate pathway, a study of its metabolism should help in studying the operation of this pathway in yeast. The reactions by which $\delta \mathrm{gl}$ is metabolized to the level of the pathway intermediates have never been investigated. Two possible routes can be envisaged (Fig. 1).

1 . The hydrolysis of $\delta \mathrm{gl}$ by the enzyme gluconolactonase to gluconic acid, which can then be phosphorylated by a gluconokinase to 6-phosphogluconate. This shunt intermediate can then be further metabolized by the enzyme 6-phosphogluconate dehydrogenase in the oxidative branch of the pentose phosphate pathway.

2. A direct phosphorylation of $\delta \mathrm{gl}$ by a lactone kinase to 6-phosphogluconolactone, followed by its hydrolysis to 6-phosphogluconate by 6-phosphogluconolactonase, another reaction of the oxidative pathway.

Although evidence exists for gluconolactonase añd gluconokinase activities in yeast extracts in vitro (Brodie \& Lipmann, 1955; Cohen, 1955), the physiological significance of these enzymes is unknown. The phosphorylation of $\delta \mathrm{gl}$ has never been demonstrated either in vitro or in vivo and therefore remains only hypothetical.

This paper investigates the specific induction of synthesis of the three enzymes, 6-phosphogluconate 


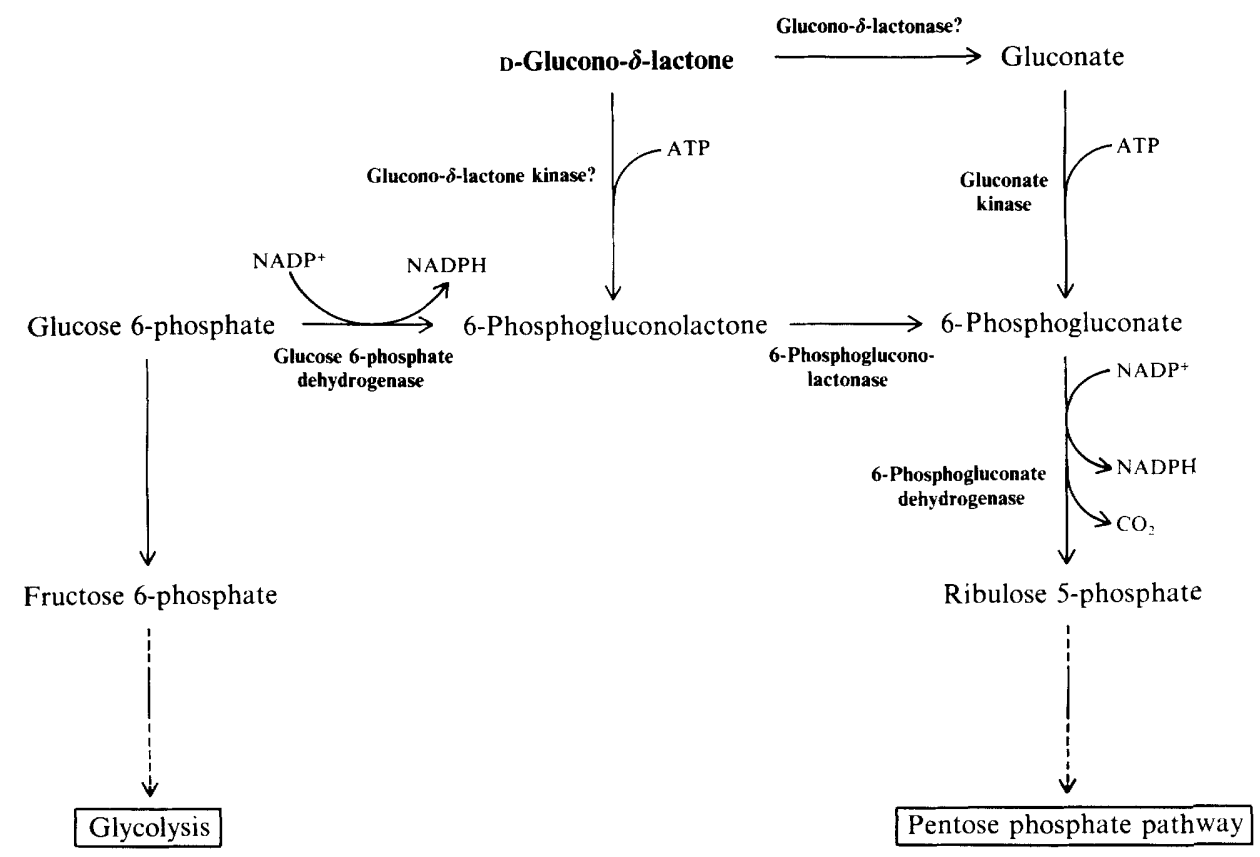

Fig. 1. Possible routes of $\delta \mathrm{gl}$ metabolism in $S$. cerevisiae.

dehydrogenase (EC 1.1.1.44), 6-phosphogluconolactonase (EC 3.1.1.31) and gluconokinase (EC 2.7.1.12) during growth of yeast on $\delta \mathrm{gl}$. The previously isolated gnd 1 mutant, which has reduced levels of GND (Lobo \& Maitra, 1982), was further characterized and found to be affected in the induction of all three enzymes by $\delta \mathrm{gl}$. Revertants of the gndl mutant with different 'induction' phenotypes have also been studied and reveal the relevance of this phenomenon, possibly under coordinate regulatory control, for the growth of yeast on $\delta \mathrm{gl}$.

\section{Methods}

Strains. The strains used in this study are listed in Table 1.

Media. Synthetic minimal medium was prepared according to Sherman et al. (1986). The enriched YEP medium containing yeast extract, peptone and carbon source has been described previously (Lobo \& Maitra, 1977). The synthetic medium was adjusted to $\mathrm{pH} 6.5$ whenever $\delta \mathrm{gl}$ was used as carbon source. All strains bearing the gndl mutation were maintained on YEP medium containing $150 \mathrm{~mm}-$ ethanol.

Chemicals. $\delta \mathrm{gl}$, D-gluconic acid, glucose 6-phosphate and 6phosphogluconate dehydrogenase were from Sigma. All other substrates and enzymes were from Boehringer Mannheim. Hybond-N membrane for Northern blotting was obtained from Amersham. Labelling of the DNA probe was done with the random primed DNA labelling kit from Boehringer Mannheim.
Enzyme assays. Enzymes were assayed fluorimetrically, either in cellfree extracts or in toluene lysates, as described previously (Maitra \& Lobo, 1971). All cell-free extracts were made in 50 mM-HEPES buffer, $\mathrm{pH} 7 \cdot 3$, containing $5 \mathrm{~mm}$-EDTA and $5 \mathrm{~mm}-\beta$-mercaptoethanol. Toluene lysates were used for assaying 6-phosphogluconate dehydrogenase in experiments on the kinetics of its induced synthesis. For this purpose, a loopful of actively growing cells was suspended in $0.5 \mathrm{ml}$ of the above-described HEPES buffer, a drop of toluene added and the mixture shaken on a reciprocating shaker at $37^{\circ} \mathrm{C}$ for $30 \mathrm{~min}$. About $50-100 \mu$ of this cell suspension was used for the assays.

All enzymes, except 6-phosphogluconolactonase, were assayed in $50 \mathrm{~mm}$-triethanolamine buffer, $\mathrm{pH} \mathrm{7.4}$, containing $10 \mathrm{mM}-\mathrm{MgCl}_{2}$.

6-Phosphogluconate dehydrogenase was assayed by following the appearance of NADPH in a $0.8 \mathrm{ml}$ reaction mixture containing 0.4 mM-6-phosphogluconate and 0.1 mM-NADP ${ }^{+}$.

Glucose-6-phosphate dehydrogenase was assayed similarly, except that $0.1 \mathrm{~mm}$-glucose 6-phosphate was used as the substrate instead of 6-phosphogluconate.

Gluconokinase was measured in discontinuous assays by incubating cell-free extract in a $0.8 \mathrm{ml}$ reaction mixture containing $5 \mathrm{mM}$-gluconate and $2 \mathrm{mM}$-ATP for $60 \mathrm{~min}$ at room temperature. The mixture was then heated in a boiling water bath for $5 \mathrm{~min}$ and the product (6phosphogluconate) assayed fluorimetrically with $0.5 \mathrm{mM}-\mathrm{NADP}^{+}$and 1 unit of 6-phosphogluconate dehydrogenase.

6-Phosphogluconolactonase was assayed by pre-incubating a $0.8 \mathrm{ml}$ reaction mixture containing $50 \mu \mathrm{M}$-glucose-6-phosphate, $0.5 \mathrm{~mm}$ $\mathrm{NADP}^{+}$and 0.5 units of glucose-6-phosphate dehydrogenase in $50 \mathrm{~mm}^{-}$ MES buffer, $\mathrm{pH} 6.5$, containing $25 \mathrm{mM}-\mathrm{KCl}$ and $10 \mathrm{mM}-\mathrm{MgCl}_{2}$, until the reaction was complete. This was followed by addition of 1 unit of 6phosphogluconate dehydrogenase which resulted in a slow increase in fluorescence due to the spontaneous hydrolysis of the lactone formed during the earlier reaction. The addition of cell-free extracts at this stage led to an enhanced rate of NADP reduction due to the lactonase reaction. The actual lactonase rate was calculated by subtracting the previous blank rate from this final rate. 
Table 1. Yeast strains used in course of this work

\begin{tabular}{|c|c|c|c|}
\hline Strain & Genotype & Source* & Remarks \\
\hline $\begin{array}{l}\text { MC3 } \\
\text { Kn79 }\end{array}$ & $\begin{array}{l}\text { MATa inol ino4 } \\
\text { MAT } \alpha \text { trplleu } 2\end{array}$ & $\left.\begin{array}{l}\text { G. R. Fink } \\
\text { B. Hall }\end{array}\right\}$ & Strains used as the wild-type \\
\hline $\begin{array}{l}\text { gnd T5A } \\
\text { gnd T9A }\end{array}$ & $\begin{array}{l}\text { MATa gnd } 1 \text { GND2 } \\
\text { MAT } \alpha \text { gnd l gnd } 2\end{array}$ & $\left.\begin{array}{l}\text { Z. Lobo } \\
\text { Z. Lobo }\end{array}\right\}$ & $\begin{array}{l}\text { gnd mutant strains used for the isolation } \\
\text { of revertants }\end{array}$ \\
\hline $\begin{array}{l}\text { gnd T10A } \\
\text { gnd T10B } \\
\text { gnd T10C } \\
\text { gnd T10D }\end{array}$ & 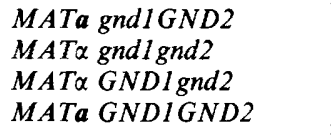 & This work & $\begin{array}{l}\text { Segregants of a tetratype tetrad from a cross } \\
\text { of the gnd Ignd } 2 \text { double mutant (gnd T9A) } \\
\text { with a wild-type strain (EG103) }\end{array}$ \\
\hline $\begin{array}{l}\text { R34 } \\
\text { R41 }\end{array}$ & & This work & $\begin{array}{l}\text { Glucose-positive revertants of strain } \\
\text { gnd T5A }\end{array}$ \\
\hline $\begin{array}{l}\text { R1 } \\
\text { R4 } \\
\text { R39 } \\
\text { R7 }\end{array}$ & & This work & $\delta$ gl-positive revertants of strain gnd T9A \\
\hline CT4 & $M A T \alpha$ gnd 1, gnd $2:: G N D 1$ & Z. Lobo & High-copy-number cDNA clone of $G N D 1$ \\
\hline
\end{tabular}

* G. R. Fink, Whitehead Institute of Biomedical Sciences, MIT, Cambridge, Mass., USA; B. Hall, University of Washington, Seattle, Wash., USA; Z. Lobo, Tata Institute of Fundamental Research, Bombay, India.

The specific activities of all the enzymes in the cell-free extracts were expressed in $\mathrm{mU}$, (i.e. nmol substrate utilized $\mathrm{min}^{-1}$ ) per $\mathrm{mg}$ total protein $\left(\mathrm{mU} \mathrm{mg}^{-1}\right)$, and that of 6-phosphogluconate dehydrogenase in toluene lysates as $\mathrm{mU}$ per $\mathrm{OD}_{650}$ unit, i.e. the optical density of the cellsuspension in a $1 \mathrm{~cm}$ pathlength cuvette at a wavelength of $650 \mathrm{~nm}[\mathrm{mU}$ $\left(\mathrm{OD}_{650}\right.$ unit $\left.^{-1}\right]$.

Total protein was estimated by the method of Bradford according to Peterson (1983), using BSA as standard.

Genetic techniques. The genetic analysis of all the mutants followed standard techniques of crossing, sporulation and tetrad dissection as described by Sherman et al. (1974).

Isolation of revertants. Mutant strains bearing the gnd I mutation were grown to late-exponential phase on YEP medium containing $150 \mathrm{mM}$ ethanol. The cells were then washed free of the medium and plated on synthetic medium, containing either $50 \mathrm{~mm}$-glucose or $50 \mathrm{~mm}-\delta \mathrm{gl}$, at approximately $5 \times 10^{7}-10^{8}$ cells per plate. The glucose plates were incubated at $30^{\circ} \mathrm{C}$ and the $\delta \mathrm{gl}$ plates at $36^{\circ} \mathrm{C}$. Not more than two or three visibly different revertant colonies were picked from a particular culture. This was done to increase the possibility of selecting revertants which arose from separate events. The colonies were purified and maintained on the appropriate restrictive medium.

Northern blot analysis. Total yeast RNA was prepared according to Carlson \& Botstein (1982) with certain modifications. About $4 \mathrm{~g}$ of sterile glass beads was added to a pellet of $100-150 \mathrm{mg}$ cells (collected during the exponential phase of growth) in $2 \mathrm{ml}$ LETS buffer containing $0.1 \mathrm{M}-\mathrm{LiCl}, 0.1 \mathrm{M}$-Tris (pH 7.5), $10 \mathrm{~mm}$-EDTA, $1 \%(\mathrm{w} / \mathrm{v})$ SDS and $0 \cdot 1 \%$ diethylpyrocarbonate. About $2 \mathrm{ml}$ of a mixture of freshly distilled phenol, chloroform and isoamyl alcohol $(25: 25: 11$, by vol.) was added immediately and the suspension vortexed vigorously for 15-30 min, with $30 \mathrm{~s}$ alternate breaking and cooling cycles. Following low-speed centrifugation for $10 \mathrm{~min}$, the upper aqueous layer was removed and the remainder extracted again with $2 \mathrm{ml}$ LETS buffer and $2 \mathrm{ml}$ of the phenol mixture. The pooled aqueous supernatant was then mixed with 0.1 vol. $5 \mathrm{M}$-potassium acetate, $\mathrm{pH} 4 \cdot 8$, and 2 vols chilled absolute ethanol and allowed to stand at $-20^{\circ} \mathrm{C}$ overnight to precipitate the RNA. After centrifugation at $12000 \mathrm{~g}$ for $15 \mathrm{~min}$, the precipitate was finally resuspended in $10 \mathrm{~mm}$-Tris, $1 \mathrm{~mm}$-EDTA, pH 8 , to a final concentration of $8-10 \mathrm{mg} \mathrm{ml}^{-1}$, as measured by the absorbance at $260 \mathrm{~nm}$.

The RNA was electrophoresed on a $1.2 \%$ formaldehyde/agarose gel in MOPS buffer exactly as described in Sherman et al. (1986). The gel was then equilibrated in $20 \times \mathrm{SSPE}$, containing $3.6 \mathrm{M}-\mathrm{NaCl}, 0.2 \mathrm{M}$ $\mathrm{NaH}_{2} \mathrm{PO}_{4}$ and $20 \mathrm{~mm}$-EDTA, pH 7.4, for $20 \mathrm{~min}$ and transferred to Hybond- $\mathrm{N}$ membrane as recommended by the supplier. Hybridization to the DNA probes was done under high stringency conditions, again using a protocol suggested by Amersham.

\section{Results and Discussion}

\section{Growth on glucono- $\delta$-lactone}

Ethanol-grown wild-type MC3 cells, when inoculated into minimal medium containing $50 \mathrm{~mm}-\delta \mathrm{gl}$, grew with a doubling time of about $10 \mathrm{~h}$ as compared to $5 \mathrm{~h}$ on $150 \mathrm{~mm}$-ethanol or $1.75 \mathrm{~h}$ on $50 \mathrm{~mm}$-glucose. The cell yield obtained, in terms of wet weight, was also significantly less than those obtained on ethanol or glucose (Table 2). Since $\delta \mathrm{gl}$ can readily hydrolyse to $\mathrm{D}$ gluconic acid in solution, the low cell yields could be due to the low amounts of unhydrolysed lactone and/or the low $\mathrm{pH}$ of the medium.

Respiration appeared to be essential for the utilization of $\delta \mathrm{gl}$; wild-type strains failed to grow on $\delta \mathrm{gl}$ anaerobically (data not shown).

\section{Induction of specific enzymes by glucono- $\delta$-lactone}

Addition of $\delta \mathrm{gl}$ to ethanol-grown cells led to a significant rise in the activities of three enzymes, 6-phosphogluconate dehydrogenase (GND), 6-phosphoglucono- 
Table 2. Growth parameters of wild-type yeast on $\delta g l$, as compared to those on ethanol and glucose

Cells of strain MC3 were grown to early exponential phase in minimal ethanol medium, washed, and inoculated into minimal media containing the respective carbon sources. Growth was monitored by recording the optical density at $650 \mathrm{~nm}$ at periodic intervals. Cell yields were measured after $3 \mathrm{~d}$ growth at $30^{\circ} \mathrm{C}$ when the cells had reached stationary phase. Colony diameters were measured following $4 \mathrm{~d}$ growth of plated cells on minimal agar medium, containing the respective carbon sources, at $30^{\circ} \mathrm{C}$. The growth parameters of yeast in liquid media were estimated twice; the values shown are representative. Colony diameters were measured from 50 randomly chosen colonies in two experiments.

\begin{tabular}{lccc}
\hline \hline $\begin{array}{c}\text { Carbon } \\
\text { source }\end{array}$ & $\begin{array}{c}\text { Doubling } \\
\text { time } \\
(\mathrm{h})\end{array}$ & $\begin{array}{c}\text { Cell yield } \\
\left(\mathrm{mg} \text { wet wt ml } \mathrm{H}^{-1}\right)\end{array}$ & $\begin{array}{c}\text { Colony } \\
\text { diameter } \\
(\mathrm{mm})\end{array}$ \\
\hline$\delta \mathrm{gl}(50 \mathrm{mM})$ & 10 & $0 \cdot 78$ & $2 \cdot 0-2 \cdot 5$ \\
Ethanol $(150 \mathrm{~mm})$ & 5 & $13 \cdot 10$ & $3 \cdot 5-4 \cdot 0$ \\
Glucose $(50 \mathrm{mM})$ & 1.75 & $14 \cdot 80$ & $5 \cdot 0-6 \cdot 0$ \\
\hline \hline
\end{tabular}

Table 3. Induction by ggl of the synthesis of enzymes of the oxidative pentose phosphate pathway and gluconokinase in wild-type yeast

All cultures, of strain $\mathrm{Kn} 79$, were grown initially on YEP ethanol medium to mid-exponential phase prior to addition of the test carbon sources. The cultures were induced for $3 \mathrm{~h}$ before cell-free extracts were prepared and the enzymes assayed, as described in Methods. Cycloheximide was added to a final concentration of $10 \mu \mathrm{g} \mathrm{ml}^{-1}$ to a culture of cells grown to mid-exponential phase in YEP ethanol medium and the culture shaken for $30 \mathrm{~min}$. $\delta \mathrm{gl}$ was then added to a concentration of $50 \mathrm{~mm}$ and the culture induced for $3 \mathrm{~h}$ before extracts were prepared. The experiment on induction of the enzymes with different carbon sources was repeated six times, cycloheximide being included in two of them; only representative results are shown.

\begin{tabular}{lcrrrr}
\hline & & \multicolumn{4}{c}{$\begin{array}{c}\text { Enzyme specific activity } \\
{[\mathrm{mU}(\mathrm{mg} \text { protein) }}\end{array}$} \\
\cline { 4 - 6 } \multicolumn{1}{c}{$\begin{array}{c}\text { Carbon } \\
\text { Soubling } \\
\text { time }\end{array}$} & $(\mathrm{h})$ & GND & PGL & GNK & GPD \\
\hline Ethanol & $3 \cdot 0$ & $59 \cdot 5$ & $5 \cdot 5$ & $17 \cdot 0$ & $144 \cdot 0$ \\
Ethanol + glucose & $1 \cdot 25$ & $74 \cdot 2$ & $7 \cdot 4$ & $20 \cdot 0$ & $148 \cdot 0$ \\
Ethanol $+\delta \mathrm{gl}$ & $2 \cdot 5$ & 616.0 & $40 \cdot 2$ & $58 \cdot 0$ & $163 \cdot 0$ \\
Ethanol $+\delta \mathrm{gl}+$ & $6 \cdot 0$ & $125 \cdot 0$ & $10 \cdot 0$ & $15 \cdot 0$ & $150 \cdot 0$ \\
cycloheximide & & & & & \\
\hline \hline
\end{tabular}

lactonase (PGL) and gluconokinase (GNK), as measured in vitro (Table 3). The increase in activity of glucose-6-phosphate dehydrogenase (GPD) was not consistently observed. The co-ordinate rise in activity of all these enzymes was evident within $15 \mathrm{~min}$ of addition of $\delta \mathrm{gl}$ and reached its peak in about 1-2 h. Although there was some variation in the basal levels of enzyme activity, GND usually showed a tenfold increase, PGL and GNK approximately fivefold (Fig. 2).

The remarkably high $\delta$ gl-induced GND specific activity of $1.4 \mathrm{U}$ (mg protein $)^{-1}$ can be compared to the specific activity - $70 \mathrm{U}(\mathrm{mg} \text { protein })^{-1}$ - of the pure enzyme (unpublished data); GND thus constitutes approximately $2 \%$ of the total cellular protein when cells are grown on $\delta \mathrm{gl}$.

The specificity of induction was restricted to these three enzymes only, since none of the glycolytic, gluconeogenic or non-oxidative pentose phosphate pathway enzymes were similarly induced. Glucose, glycerol, xylulose and gluconate, on the other hand, failed to induce the $\delta$ gl-inducible enzymes (data not shown).

The rise in activity of all three enzymes was sensitive to the addition of cycloheximide to a growing culture, implicating de novo protein synthesis during the process of induction (Table 3). The growth rate of the culture was, however, only slightly reduced during this treatment.

\section{Induction of 6-phosphogluconate dehydrogenase: kinetics}

Since the specific activity of GND is fairly high, the enzyme can be detected easily in permeabilized yeast cells. An investigation was therefore made into the kinetics of induction of this enzyme.

The differential rates of synthesis of GND during growth on ethanol, in the presence and absence of the inducer, are shown in Fig. 3. Enzyme synthesis on $\delta \mathrm{gl}$, as sole carbon source, began to fall off as the cells reached stationary phase, usually within $24 \mathrm{~h}$ of growth. The sustained synthesis when ethanol was also present indicated a role for the latter more as an easily available energy source; by itself, ethanol supported only the constitutive level of synthesis.

The initial and final rates of enzyme synthesis, as well as the final levels of enzyme activity reached, were dependent on the inducer concentration used (Fig. 4). Thus, the rate of GND synthesis increased between 5and $25 \mathrm{~mm}$ - $\delta \mathrm{gl}$, while the steady-state enzyme level was even higher at $50 \mathrm{~mm}-\delta \mathrm{gl}$. Withdrawal of $\delta \mathrm{gl}$ during the course of induction halted further enzyme synthesis, suggesting that the continued presence of the inducer is essential for maintenance of the induced state (data not shown).

\section{Pleiotropic effects of the gndl and gnd 2 mutations}

The gnd I gnd 2 double mutant, isolated previously in this laboratory as a glucose-negative, GND-deficient strain (Lobo \& Maitra, 1982), exhibited extremely slow growth in minimal medium with $50 \mathrm{mM}-\delta \mathrm{gl}$ at $30^{\circ} \mathrm{C}$, while 

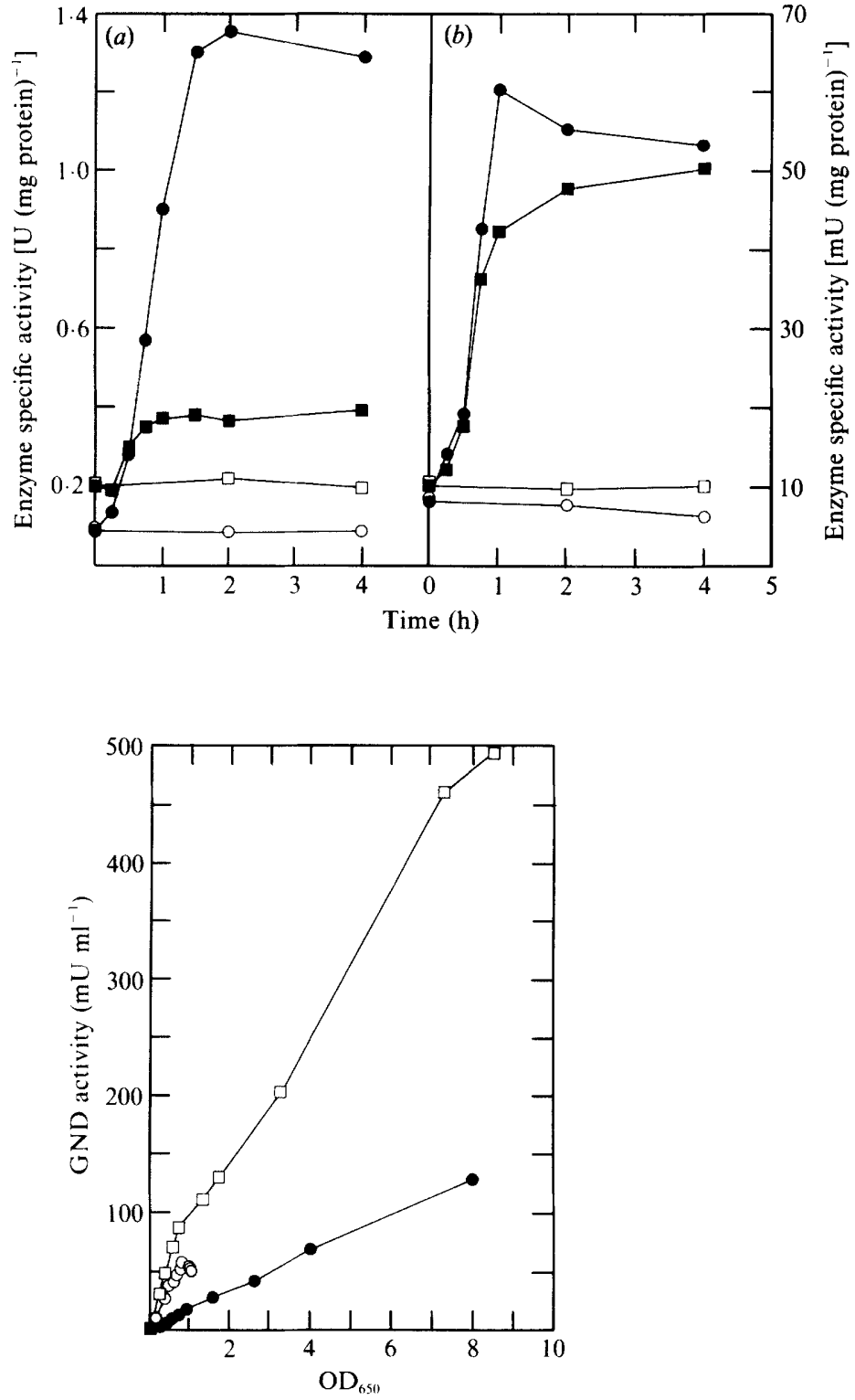

Fig. 3. Differential rate of the increases in activity of GND in fully induced cultures. Cells of strain MC3, growing exponentially in YEP media with $150 \mathrm{~mm}$-ethanol and $50 \mathrm{~mm}-\delta \mathrm{gl}$, individually and in combination, were re-inoculated into fresh media at a density of about $3-6 \times 10^{7}$ cells $\mathrm{ml}^{-1}$. Samples of the cultures $(O$, ethanol; $O, \delta \mathrm{gl} ; \square$, ethanol $+\delta \mathrm{gl})$ were then removed at intervals and GND activity was assayed in toluene lysates, as described in Methods. Representative results for the two experiments performed are shown.

growth was completely inhibited at $36^{\circ} \mathrm{C}$ (Table 4). A segregant bearing the gnd 1 mutation alone retained $20 \%$ of wild-type GND activity but showed the same phenotype as that of the double mutant. The glucosepositive gnd 2 mutant, with approximately $80 \%$ wild-type activity, was, however, comparable to the wild-type strain in its growth on $\delta \mathrm{gl}$.
Fig. 2. Kinetics of the increases in activity of GND, GPD, PGL and GNK on induction with $\delta \mathrm{gl}$. Two cultures of strain MC3 were grown in YEP ethanol medium. $\delta \mathrm{gl}$ was added at time zero to a final concentration of $50 \mathrm{~mm}$ to one culture (filled symbols), growing exponentially (cell density about $10^{7}$ cells $\mathrm{ml}^{-1}$ ). No additions were made to the other, control culture (open symbols). Samples of the cultures were removed at the indicated time intervals and the specific activity of the enzymes measured in cell-free extracts, as described in Methods. This experiment was repeated three times; the results shown are representative. (a) GND $(O, \bullet)$ and GPD $(\square, \square) ;(b)$ PGL $(O, \bullet)$ and GNK $(\square, \mathbf{c})$.

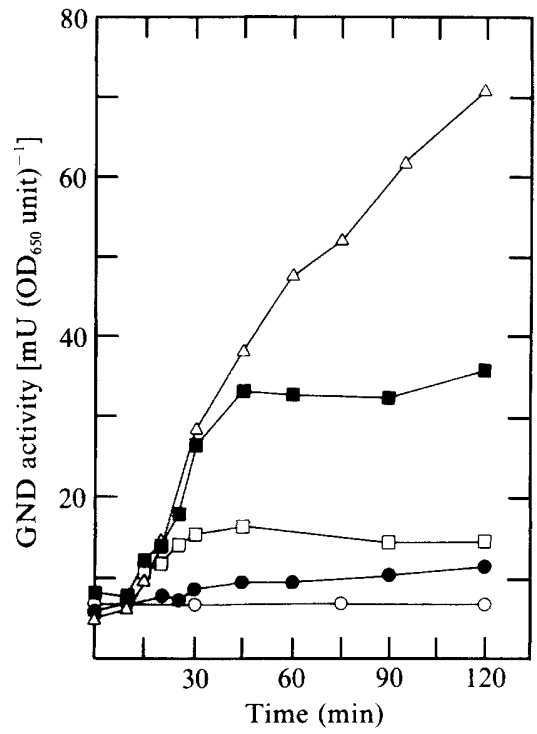

Fig. 4. Effect of inducer concentration on the kinetics of increases in GND activity. A culture of strain MC3, grown to early exponential phase (about $10^{7}$ cells $\mathrm{ml}^{-1}$ ) on YEP ethanol medium, was divided into five equal portions, and to four of these $\delta \mathrm{gl}$ was added at $5(\odot), 10(\square)$, $25(\square)$ and $50(\triangle) \mathrm{mM}$, respectively. One portion was maintained without inducer $(O)$. Samples of the cultures were then removed at the indicated time intervals and GND activity was assayed in toluene lysates, as described in Methods. This experiment was repeated twice; representative results are shown.

The gnd 1 mutant was found, rather surprisingly, to be totally lacking in the $\delta$ gl-induced synthesis of all three enzymes, GND, PGL and GNK (Table 4). The gnd 2 mutant was only partially affected, the inducibility of the enzymes being approximately $25 \%$ of that in the wildtype strain. 
Table 4. Comparison of the constitutive and $\delta g l$-induced levels of enzymes of the oxidative pentose phosphate pathway and gluconokinase in the gndl and gnd 2 mutants, different revertants of the gnd 1 mutant and a strain carrying the cDNA clone which complements the gnd 1 mutation

The doubling time of the strains was measured in minimal medium containing either $150 \mathrm{~mm}$-ethanol (EtOH) at $30^{\circ} \mathrm{C}$ or $50 \mathrm{~mm}-\delta \mathrm{gl}$ at $36^{\circ} \mathrm{C}$. This experiment was repeated twice; representative values are shown. For the measurement of induced enzymes, the cultures were grown to early exponential phase in YEP ethanol media and induced with $50 \mathrm{~mm}-\delta \mathrm{gl}$ for $3 \mathrm{~h}$ at $30^{\circ} \mathrm{C}$. Cell-free extracts were made and the enzymes assayed as described in Methods. The results shown are representative of the four experiments performed. The genotypes of the gnd mutants are listed in Table 1, while the phenotypes of the revertants and the cDNA clone are described in the text.

\begin{tabular}{|c|c|c|c|c|c|c|c|c|c|c|}
\hline \multirow[b]{3}{*}{ Strain } & \multirow{2}{*}{\multicolumn{2}{|c|}{$\begin{array}{c}\text { Doubling } \\
\text { time } \\
\text { (h) }\end{array}$}} & \multicolumn{8}{|c|}{ Enzyme specific activity [mU (mg protein $\left.)^{-1}\right]$} \\
\hline & & & \multicolumn{2}{|c|}{ GND } & \multicolumn{2}{|c|}{ PGL } & \multicolumn{2}{|c|}{ GNK } & \multicolumn{2}{|c|}{ GPD } \\
\hline & EtOH & $\delta \mathrm{gl}$ & EtOH & $\delta \mathrm{gl}$ & EtOH & $\delta \mathrm{gl}$ & $\mathrm{EtOH}$ & $\delta \mathrm{gl}$ & EtOH & $\delta \mathrm{gl}$ \\
\hline gnd $\mathrm{T} 10 \mathrm{~A}$ & $6 \cdot 5$ & 38 & 19 & 23 & 6 & 10 & 30 & 32 & 245 & 247 \\
\hline gnd T10B & 9 & $>45$ & 11 & 12 & 7 & 9 & 19 & 19 & 208 & 222 \\
\hline gnd $\mathrm{T} 10 \mathrm{C}$ & $6 \cdot 5$ & 15 & 47 & 226 & 7 & 15 & 16 & 38 & 210 & 173 \\
\hline gnd T10D & $4 \cdot 5$ & 13 & 69 & 814 & 6 & 35 & 15 & 70 & 200 & 212 \\
\hline R34 & 5 & 19.5 & 51 & 49 & 9 & 7 & 27 & 27 & 213 & 194 \\
\hline R41 & $5 \cdot 5$ & $>24$ & 41 & 45 & 7 & 10 & 15 & 13 & 173 & 171 \\
\hline R39 & 7 & 10 & 90 & 800 & 10 & 56 & 32 & 86 & 209 & 235 \\
\hline R7 & $5 \cdot 5$ & $9 \cdot 5$ & 18 & 22 & 9 & 9 & 64 & 71 & 364 & 324 \\
\hline CT4 & 6 & $>24$ & 3777 & 4102 & 45 & 31 & 15 & 14 & 272 & 273 \\
\hline
\end{tabular}

It was important to examine the possibility that the gnd l mutant may harbour yet another mutation responsible for its inability to be induced for the enzymes PGL and GNK. A gndl segregant, gnd T5A, was therefore crossed to the wild-type strain $\mathrm{Kn} 79$, and 15 complete tetrads were analysed for glucose-negativity, the ability to grow on $\delta \mathrm{gl}$, and constitutive as well as induced GND activity. The characteristic glucose-negativity of the gnd 1 lesion co-segregated $2^{+}: 2^{-}$with the phenotypic lack of induction of GND and $\delta$ gl-negativity in all tetrads, indicating that these three phenotypes are very tightly linked.

\section{Reversion studies of the gndl mutant}

Spontaneous revertants of the gndl mutant were obtained using two independent selection schemes: the ability to grow on glucose at $30^{\circ} \mathrm{C}$ and on $\delta \mathrm{gl}$ at $36{ }^{\circ} \mathrm{C}$. Both the gndl mutant (strain gnd T5A) and the gnd 1 gnd 2 double mutant (strain gnd T9A) yielded similar kinds of revertants - an indication that the gnd 2 lesion does not by itself exert any selection pressure for revertants to arise.

\section{Glucose-positive revertants of the gnd I mutant}

The majority of glucose-positive revertants of gnd 1 have been reported to be deficient in GPD activity (Lobo \& Maitra, 1982). All of the revertants selected were thus assayed for GPD, and 30 back-revertants showing constitutive GPD and GND activity were analysed for growth on $\delta \mathrm{gl}$. None of these revertants could grow on $\delta \mathrm{gl}$ at $30^{\circ} \mathrm{C}$ or at $36^{\circ} \mathrm{C}$ and were also completely deficient in their ability to be induced for all three enzymes, GND, PGL and GNK, by $\delta \mathrm{gl}$. The activities of these enzymes in two such revertants (R34 and R41) of strain gnd T5A are shown in Table 4.

To determine the nature of the reversion events, the two revertants R34 and R41 were subjected to tetrad analysis in crosses with the wild-type strain $\mathrm{Kn} 79$. Twenty complete tetrads were dissected in each cross. All the tetrads of the R34 cross segregated $4^{+}: 0^{-}$for growth on glucose, implicating a locus tightly linked to the gndl mutation for the reversion. The tetrads of the R41 cross, on the other hand, segregated differently for glucose-positivity, the numbers of parental ditype $\left(4^{+}: 0^{-}\right)$, non-parental ditype $\left(2^{+}: 2^{-}\right)$and tetratype $\left(3^{+}: 1^{-}\right)$tetrads being five, one and fourteen respectively. R41 had clearly reverted at an extragenic locus.

\section{Glucono- $\delta$-lactone revertants of the gnd1 mutant}

Approximately 200 revertants of the strains gnd T5A and gnd T9A, capable of growth on $\delta \mathrm{gl}$ at $36{ }^{\circ} \mathrm{C}$, were analysed for the inducibility of GND by $\delta \mathrm{gl}$. Since the loss of GPD activity did not enable the gndl mutant to grow on $\delta \mathrm{gl}$ (unpublished observations), such mutants were never selected for. All the revertants obtained by this selection fell into either of the two following phenotypic classes. 
One class of revertants, typically represented by strain R39, was capable of limited growth on glucose and had regained the normal constitutive levels of GND as well as inducibility of all three enzymes by $\delta \mathrm{gl}$ (Table 4 ). Three such randomly chosen revertants, R1, R4 and $\mathrm{R} 39$, were subjected to tetrad analysis in crosses with the wild-type strain $\mathrm{Kn} 79$. Twenty tetrads, dissected in each of two crosses (R1 and R4), and 17 tetrads, dissected in the third cross (R39), segregated $4^{+}: 0^{-}$for growth on $\delta \mathrm{gl}$ and for $\delta \mathrm{gl}$-induced GND synthesis, indicating that all three strains had reverted in loci tightly linked to the original gndl lesion.

The other class of revertants, typically represented by strain $\mathrm{R} 7$, grew slowly on $\delta \mathrm{gl}$ at $30^{\circ} \mathrm{C}$ and at $36^{\circ} \mathrm{C}$ but remained glucose-negative. These revertants possessed constitutively high levels of GNK although their GND and PGL levels remained comparable to the gndl parent (Table 4). Nine tetrads, obtained in a cross between strain $\mathrm{R} 7$ and the wild-type $\mathrm{Kn} 79$, segregated $2^{+}: 2^{-}$for growth on glucose. However, they segregated differently for growth on $\delta \mathrm{gl}$, the number of parental ditype $\left(4^{+}: 0^{-}\right)$, non-parental ditype $\left(2^{+}: 2^{-}\right)$and tetratype $\left(3^{+}: 1^{-}\right)$ tetrads being one, three and four respectively. The recovery of $\delta$ gl-negative progeny in this cross confirmed the extragenic nature of this reversion. The occurrence of two $\delta$ gl-positive spores in the non-parental ditype tetrads also showed that the revertant locus, by itself, did not affect growth on $\delta \mathrm{gl}$. Moreover, these segregants had high levels of GNK activity, clearly establishing that this effect was mediated by the revertant locus independent of the gnd 1 allele.

Direct evidence that the induction process has a meaningful role in $\delta \mathrm{gl}$ metabolism comes from the gndI mutant. Glucose-positive revertants of this mutant, with restored constitutive GND levels, do not show induction of any of the enzymes by $\delta \mathrm{gl}$ and also fail to grow on this compound. In contrast, revertants selected for growth on $\delta \mathrm{gl}$ regained the 'induction' phenotype to wild-type levels. There is thus a clear correlation between the ability of $\delta \mathrm{gl}$ to mediate induction and the ability of cells to use this compound as a carbon source.

The $\delta$ gl-positive revertants of the gndl mutant with elevated constitutive levels of GNK were able to grow slowly on $\delta \mathrm{gl}$, although GND and PGL were not induced to normal levels. GNK activity in vivo may thus be the rate-limiting step in $\delta \mathrm{gl} \mathrm{metabolism,} \mathrm{with} \mathrm{the} \mathrm{need} \mathrm{for} \mathrm{its}$ induction being more critical than those of GND and PGL.

\section{Analysis of a cDNA clone complementing the gnd I mutation}

A multicopy $1.65 \mathrm{~kb}$ cDNA clone, complementing the gnd I mutation, had been isolated previously and shown to correspond to the structural gene for the major GND isoenzyme ( $Z$. Lobo \& P. K. Maitra, unpublished results). This clone (CT4) had high constitutive GND levels, though its GNK activity was comparable to that in the gndlgnd 2 double mutant (Table 4). The PGL levels were also remarkably elevated in this clone. It was, however, totally deficient in the inducibility of all the three enzymes and failed to grow on $\delta \mathrm{gl}$ at $36^{\circ} \mathrm{C}$, although growth on glucose was restored to the wild-type level.

The inability of cells carrying GNDI cDNA to grow on $\delta \mathrm{gl}$ in spite of elevated constitutive GND and PGL levels is not surprising, since they lack the 'induction' phenotype and consequently have a low level of GNK, comparable to that of the gnd I gnd 2 double mutant. This further supports the view that GNK activity levels may be most critical in the metabolism of $\delta \mathrm{gl}$, at least in the oxidative part of the pathway.

Identification of the importance of GNK activity for growth of yeast on $\delta \mathrm{gl}$ could indicate that the metabolism of this compound proceeds preferentially by an initial conversion to gluconate rather than its direct phosphorylation to 6-phosphogluconolactone (Fig. 1). If this is true, more attention should be paid to the gluconolactonase activity reported by Brodie \& Lipmann (1955). Does this enzyme also exhibit induction by $\delta \mathrm{gl}$ ? Our efforts to study this enzyme failed due to the instability of its substrate in solution, making the enzyme difficult to assay.

Molecular expression of the GND1 gene on induction with glucono- $\delta$-lactone

The synthesis of most inducible proteins is governed at the level of transcription. Since a functional GND1 gene appears to be essential for induction of GND synthesis, it was of interest to ascertain whether transcription from this gene was involved in induction. A $0.65 \mathrm{~kb} \mathrm{SalI}$ internal fragment from the above-mentioned cDNA clone was therefore used in a Northern blot to probe total RNA prepared from the wild-type and the gnd 1 and gnd 2 mutants, as well as the different revertants, grown on ethanol with and without inducer.

Induction of GND synthesis correlates with the simultaneous appearance of a specific $1.6 \mathrm{~kb}$ mRNA species at fairly high levels during the growth of cells on $\delta \mathrm{gl}$ (Fig. 5). This transcript was, however, absent in strains bearing the gndl mutation, both constitutively and on induction. The effect, if any, of the gnd 2 mutation on the transcript level was not apparent in this experiment.

The $\delta$ gl-positive revertant $\mathrm{R} 39$ was comparable to the wild-type in the induction of its transcript by $\delta \mathrm{gl}$. The glucose-positive revertants, R34 and R41, however, 

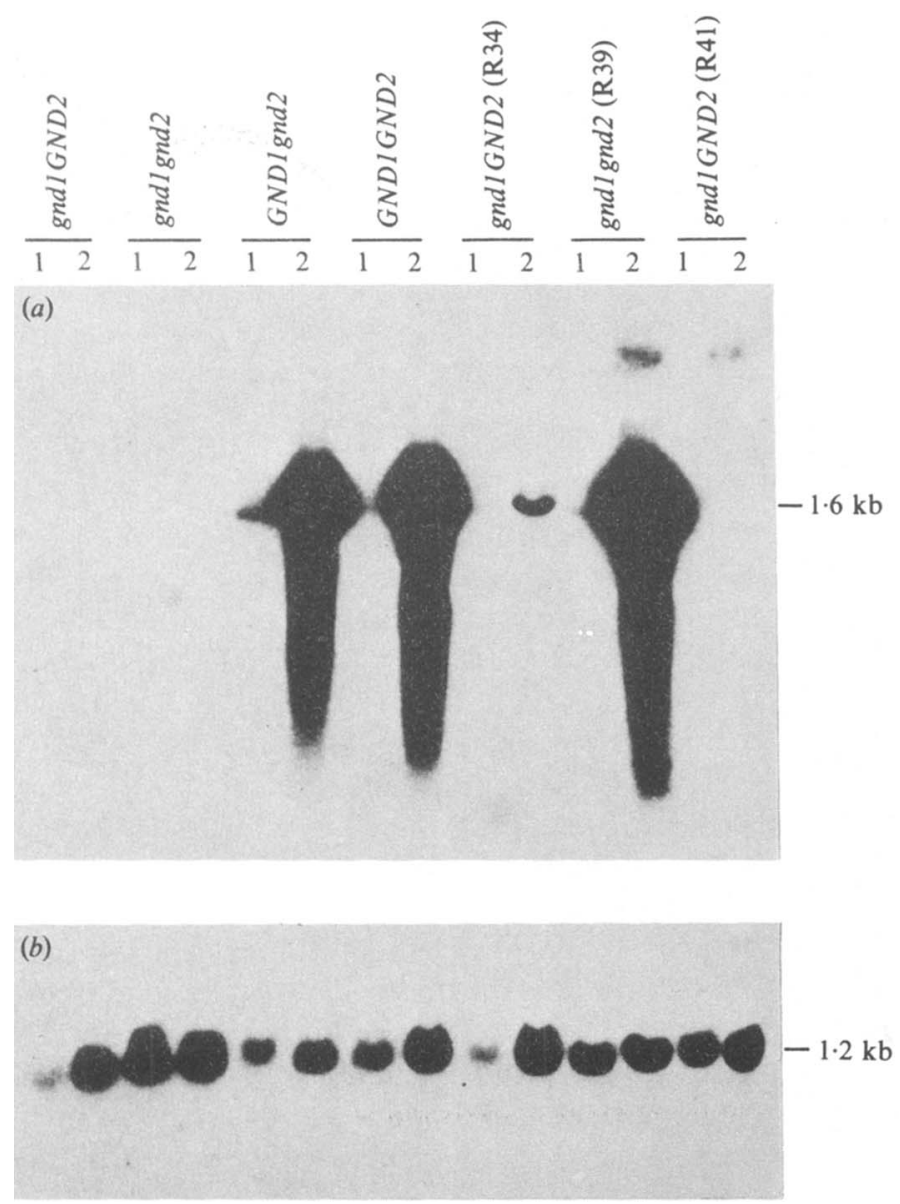

Fig. 5. Northern blot analysis of wild-type yeast, the gnd Ignd 2 mutants and different gndl revertants, probed with a GNDI cDNA. Total yeast RNA was isolated from wild-type yeast (gnd T10D), the gnd mutants (gnd T10A, gnd T10B and gnd T10C) and the gnd l revertants $\mathrm{R} 34, \mathrm{R} 41$ and $\mathrm{R} 39$, as described in Methods. A $0.65 \mathrm{~kb}$ SalI fragment of the DNA clone CT4 was used as the probe for hybridization. The $18 \mathrm{~S}$ and $23 \mathrm{~S}$ ribosomal RNA served as size standards. (a) Northern blot of yeast cultures grown in YEP ethanol medium (lane 1) and YEP ethanol medium containing $\delta \mathrm{gl}$ (lane 2). (b) Northern blot after washing and reprobing the same filter with a genomic clone for the enzyme fructose bisphosphate aldolase $(1.2 \mathrm{~kb})$ as a control. failed to induce the GND mRNA to the same level under the same conditions. These were also the revertants that did not induce the $\delta \mathrm{gl}$-metabolizing enzymes, as assayed in vitro. Although $\mathrm{R} 34$ did show a low level of the transcript on induction, R41 lacked the message completely. These two strains had reverted at different loci, only one of which (that in R34) was linked to the original gndl mutation.

Attention can now be focussed on the role of the GND1 gene in induction. That the GNDI gene-product per se is not involved in this process is evident from the failure of the cDNA clone of this gene to induce these enzymes. Recent work in this laboratory has established that the original gndl mutant contains an extensive deletion (upward of $6 \mathrm{~kb}$ ), covering almost two-thirds of the 5' end of the GND1 gene (Z. Lobo, unpublished results). This deletion thus spans at least $5 \mathrm{~kb}$ of the $5^{\prime}$ upstream region of this gene. It is therefore quite likely that the induction could actually be mediated by the product of some other gene linked to GNDI and covered by this deletion, an implicit assumption being that the GNDI gene itself codes for the major GND isoenzyme.

Although these results indicate a key role for an intact regulatory locus, possibly upstream of the GND1 gene, neither the nature of its product nor the step at which it acts have been defined by these experiments. It could, for example, be involved in the initiation of transcription or in the stabilization of constitutively produced but rapidly degraded transcripts. One cannot distinguish between these possibilities at present. Determination of the exact role of the putative regulatory locus must await the isolation and analysis of the specific sequences upstream of the GNDl gene, and the identification and characterization of the inducing factor(s).

Induction of all the three enzymes involves de novo protein synthesis. Northern blot analysis indicates that the induction of GND enzyme activity correlates with levels of GND transcript greater than those occurring constitutively in ethanol-grown cells. Although it has not yet been possible to investigate the regulation of the 
genes coding for PGL and GNK, they may be regulated co-ordinately by the above-mentioned putative locus at the level of transcription.

What is the exact role of this catabolic pathway? $\delta \mathrm{gl}$ is a most unlikely natural substrate. Has this pathway evolved to remove metabolic intermediates, the accumulation of which might prove toxic to the cell? The gndl mutant fails to grow on glucose while a $z w f 1$ gnd 1 double mutant, which also lacks GPD, can (Lobo \& Maitra, 1982). This could imply that the intermediates of the oxidative pathway (6-phosphogluconolactone and/or 6phosphogluconate) inhibit glucose metabolism if accumulated to non-physiological levels. Thus, the importance of the $\delta \mathrm{gl}$-induced enzymes may be to prevent the deleterious accumulation of these otherwise-necessary metabolites in the cell.

We are deeply indebted to Zita Lobo for her numerous illuminating insights into this problem, and also for letting us freely use her strains and unpublished data whenever required. We would also like to thank Harry William for his excellent illustrations and Amitava Chaudhuri, Raghavendra Gadagkar, Archana G. Gayatri, Niranjan V. Joshi, S. Mahadevan and Vidyanand Nanjundiah for critical comments on an earlier version of this manuscript.

\section{References}

Brodie, A. F. \& LipMaNN, F. (1955). Identification of a gluconolactonase. Journal of Biological Chemistry 212, 677-685.

CARLSON, M. \& Botstein, D. (1982). Two differentially regulated mRNAs with different $5^{\prime}$ ends encode secreted and intracellular forms of yeast invertase. Cell 28, 145-154.

CoHEN, S. S. (1955). Gluconokinase. Methods in Enzymology 1, 350354.

Fraenkel, D. G. (1982). Carbohydrate metabolism. In The Molecular Biology of the Yeast Saccharomyces. Metabolism and Gene Expression, pp. 1-37. Edited by J. N. Strathern, E. W. Jones \& J. R. Broach. Cold Spring Harbor, NY: Cold Spring Harbor Laboratory.

FraenKel, D. G. (1986). Mutants in glucose metabolism. Annual Review of Biochemistry 55, 317-337.

GANCEDO, C. \& DELGADO, M. A. (1984). Isolation and characterization of a mutant from Saccharomyces cerevisiae lacking fructose 1,6bisphosphatase. European Journal of Biochemistry 139, 651-655.

Lobo, Z. \& MaItra, P. K. (1977). Genetics of yeast hexokinase. Genetics 86, 727-744.

LoBo, Z. \& MAITRA, P. K. (1982). Pentose phosphate pathway mutants of yeast. Molecular and General Genetics 185, 367-368.

MaItRa, P. K. \& LoBo, Z. (1971). A kinetic study of glycolytic enzyme synthesis in yeast. Journal of Biological Chemistry 246, 475-488.

Peterson, G. L. (1983). Determination of total protein. Methods in Enzymology 91, 95-119.

Sherman, F., Fink, G. R. \& Hicks, J. B. (1974). Laboratory Course Manual for Methods in Yeast Genetics. Cold Spring Harbor, NY: Cold Spring Harbor Laboratory.

Sherman, F., Fink, G. R. \& Hicks, J. B. (1986). Laboratory Course Manual for Methods in Yeast Genetics. Cold Spring Harbor, NY: Cold Spring Harbor Laboratory. 